the opportunity to engage in the consummatory or terminal response of a complex behavioral sequence may act to strengthen appropriate appetitive (instrumental) behavior. Demonstrations of the reinforcing properties of young for the postpartum rat (Wilsoncroft, 1969), nesting material for the hamster (Jansen et al, 1969), and the imprinting object for the duckling (Campbell \& Pickleman, 1961), as well as the results of the present report, support this view and further extend the category of environmental events that may serve to reinforce new learning.

\section{REFERENCES}

CAMPBELL, B. A., \& PICKLEMAN, J. R. The imprinting object as a reinforcing stimulus. Journal of Comparative \& Physiological Psychology, 1961, 54, 592-596.

GLICKMAN, S. E., \& SCHIFF, B. B. A biological theory of reinforcement. Psychological Review, 1967, 74, 81-109.

JANSEN, P. E., GOODMAN, E. D., JOWAISAS, D., \& BUNNELL, B. N. Paper as a positive reinforcer for acquisition of a bar press response by the golden hamster. Psychonomic
Science, 1969, 16, 113-114.

KINDER, L. F. A study of the nestbuilding activity of the albino rat. Journal of Experimental Zoology, 1929, 47, 117-161.

KING, J. A., \& WEISMAN, R. G. Sand digging contingent upon bar pressing in deermice (Peromyscus). Animal Behaviour, 1964, 12 , 446-450.

LAYNE, J. N. Nest-building behavior in three species of deer mice, Peromyscus. Behaviour, $1969,35,288-303$.

LISK, R. D., PRETLOW, R. A., \& FRIEDMAN, S. M. Hormonal stimulation necessary for elicitation of maternal nestbuilding in the mouse (Mus musculus). Animal Behaviour, $1969,17,730-737$.

RICHTER, C. P. Self-regulatory functions during gestation and lactation. In G. B. Wislocki (Chm.), Gestation: Transactions of the second conference, March 8, 9, and 10, 1955. Princeton, N.J: Princeton University Press, 1955. Pp. 11-89.

TEITELBAUM, P. The use of operant methods in the assessment and control of motivational states. In W. K. Honig (Ed.), Operant behavior. New York: Appleton-Century-Crofts, 1966. Pp. 565-608.

TINBERGEN, N. The study of instinct. Oxford: Clarendon Press, 1951.

WILSONCROFT, W. E. Babies by bar-press: Maternal behavior in the rat. Behavior Research Methods \& Instrumentation, 1969, 1, 229-230.

\title{
Effect of ECS on one-trial learning following continuous- and partial-reinforcement training*
}

\author{
A. GRANT YOUNG and E. H. GALLUSCIO \\ Louisiana State University, Baton Rouge, La. 70803
}

Thirty-two naive male albino rats were trained to leverpress for sucrose using a discrete trial procedure. Half of the Ss were trained on a continuous-reinforcement schedule (CRF) and the other half were trained on a fixed-ratio schedule (FR). Following acquisition, for half of the $S$ s in each group, a leverpress produced footshock followed by ECS. For the remaining Ss a leverpress produced footshock only. Results showed that suppression of the leverpress response due to footshock was reduced by the ECS, regardless of the acquisition reinforcement schedule. Results also showed that FR-trained Ss failed to show the partial-reinforcement effect in extinction.

The fact that electroconvulsive shock (ECS) seems to produce retrograde amnesia (RA) when administered shortly after a learning trial is well established (Lewis, 1969; Spevack \& Suboski, 1969). The selective disruption of recent memory by ECS has been accounted for by the concept of memory consolidation, which suggests that the fixation of the physiological substrate of memory is time-dependent (McGaugh, 1966). It is assumed that following registration of an experiential event, some type of short-term process maintains the memory trace until a

*This research was supported in part by a grant from the Graduate Research Council, LSU, to the first author. more permanent physical trace is fixed. Although the short-term process is susceptible to disruption, the structural changes effected by the consolidation process are relatively impervious to amnesic agents. Presumably, then, the massive electrical interference of ECS disrupts the consolidation process and thereby prevents the permanent fixation of the memory trace.

Although a number of studies (e.g., Heriot \& Coleman, 1962; Madsen \& McGaugh, 1961) have shown that a single ECS does not appear to be aversive, Hudspeth, McGaugh, \& Thompson (1964) have shown that repeated ECS treatments are aversive. Spevack \& Suboski (1969) have suggested that only those experimental procedures in which the amnesic and aversive effects of ECS have separable behavioral outcomes bear on consolidation theory. A typical procedure is to administer aversive stimulation, such as footshock, upon the emission of a previously learned response. The aversive stimulation results in a suppressed rate of responding; however, if ECS is administered shortly after the aversive stimulation, the result seems to be RA for this one-trial learning.

Recently Young \& Galluscio (1970) reported findings that do not support a consolidation interpretation of the effects of ECS. In that study two groups of rats were trained to leverpress, one group on a continuous-reinforcement schedule (CRF) and the other on a fixed-ratio schedule (FR 5). Upon completion of acquisition, on pretest day a leverpress was followed by footshock. For half the Ss in each group, footshock was followed by ECS; the other half received no ECS. All Ss were then tested during an extinction session. Results showed that during extinction the CRF group that received ECS following footshock made significantly more responses than did the CRF group that received footshock only. However, both FR 5 groups showed significantly suppressed response rates, not significantly different from each other, although one group had received footshock plus ECS and the other group had received footshock only. Thus, ECS did not eliminate suppression of response rate following training on a FR schedule.

Although these findings do not support consolidation theory, they are difficult to interpret because it is not clear whether ECS failed to eliminate suppression in the FR group due to the partial reinforcement schedule itself or due to the high response rate that a partial reinforcement schedule generates.

The present study was therefore designed to evaluate the effect of ECS on response suppression following training under FR and CRF conditions with relative response rates during training controlled by the use of a discrete-trial procedure. SUBJECTS

The Ss were 32 naive male albino rats, $150-175 \mathrm{~g}$ in weight at the start of the experiment.

\section{APPARATUS}

The apparatus consisted of two identical Scientific Prototype operant chambers, each enclosed in a sound-insulated, ventilated box. Each operant chamber had a grid floor, and fitted on the end wall was a retractable lever and a liquid dipper that dispensed $.01 \mathrm{ml}$ of a $40 \%$ sucrose solution, used as reinforcement. All E-controlled events were operated by an electronic 
Table 1

Mean Number of Lever Presses in Extinction

\begin{tabular}{lcc}
\hline Group & $\begin{array}{c}\text { Mean } \\
\text { Responses } \\
\text { First Minute }\end{array}$ & $\begin{array}{c}\text { Total } \\
\text { Mean } \\
\text { Responses }\end{array}$ \\
\hline CR (ECS) & 12.37 & 62.75 \\
FR (ECS) & 9.00 & 50.75 \\
CR (SO) & 5.62 & 35.12 \\
FR (SO) & .87 & 29.62 \\
\hline
\end{tabular}

programming device.

\section{PROCEDURE}

Upon arrival at the laboratory, $S$ s were placed in individual cages and kept on an ad lib food and water schedule for 4 days, after which Ss were placed on a food-deprivation schedule of $10 \mathrm{~g}$ Purina chow every $24 \mathrm{~h}$. Water was available in the cages at all times, and $S$ s were fed approximately $10 \mathrm{~min}$ after each experimental session.

From the 5 th to the 9 th day, Ss were handled in pairs for $5 \mathrm{~min}$ daily, and on the 10th day, Ss began magazine training on a VI 30-sec schedule. Experimental periods consisted of 20 presentations of the dipper and were continued for 4 days. On the 14th day all Ss were conditioned to leverpress and on the following day were allowed to make 100 reinforced responses. On the 16th day, Ss were divided randomly into two groups, FR and $C R$, and began acquisition training. For the FR group, acquisition was under a FR 2 reinforcement schedule for the first 5 days and under FR 3 for the remainder of acquisition training. For the $C R$ group, acquisition was under a CRF schedule throughout. All Ss were given 100 leverpresses daily for 10 days. A discrete-trial procedure was used and the lever, which required $4 \mathrm{sec}$ to retract and extend fully, was inoperative during retraction.

On the day following completion of acquisition, each group was subdivided randomly, resulting in the following four groups, with eight Ss per group: CR(ECS), FR(ECS), CR(SO), and FR(SO).

Groups CR(ECS) and FR(ECS)-On treatment day the $S s$ in these two groups were fitted with a harness. Fine wire from an ECS source that entered the operant chamber from the top was connected to the harness and from the harness to microalligator clips that attached to S's ears. The harness arrangement permitted complete freedom of movement to all parts of the operant chamber. The first leverpress produced a 9-mA footshock of $2 \mathrm{sec}$ duration, delivered through the grid floor, and the lever retracted. The offset of footshock initiated the onset of a $50-\mathrm{mA}$, 500-msec ECS delivered through the ear-clip electrodes.

Groups CR(SO) and FR(SO)-For Ss in these two groups, treatment was identical to the two groups above, except that footshock was not followed by ECS.

On the day following treatment, Ss were subjected to a $10-\mathrm{min}$ extinction session. During extinction the stimulus conditions were the same as during acquisition, except that the dipper was inoperative.

\section{RESULTS}

The number of responses made by each $S$ in extinction was recorded at the end of the first minute and at the end of the 10 -min periad. The results for both time periods showed that more responses were made by Group CR(ECS), followed in order by Groups FR(ECS), CR(SO), and FR(SO). The data for the first minute were subjected to an analysis of variance that showed that the effect of reinforcement schedule was significant beyond the .05 level and the treatment effect was significant beyond the .01 level. The Schedule by Treatment interaction was not significant.

The total number of responses made by each $S$ for the 10-min period was subjected to the same statistical analysis, which showed that only the treatment main effect was significant $(\mathrm{p}<.01)$. The mean number of responses in extinction for all groups is shown in Table 1.

Table 2 shows group mean response rates on the last 2 days of acquisition, the first minute of extinction, and for the full 10-min extinction period. Acquisition response rates were significantly lower for FR Ss than for CRF Ss $(p<.001$, Mann-Whitney U test). A comparison of response rates for the first minute on test day shows Group FR(SO) significantly slower than Group FR(ECS) $(p<.001)$, and Group CR(SO) significantly slower than Group CR(ECS) $(\mathrm{p}<.05$, Mann-Whitney U). A comparison of response rates for the full 10 -min period on test day shows Group FR(SO) significantly slower than Group FR(ECS) ( $p<.01)$, and Group CR(SO) significantly slower than Group CR(ECS) $(\mathrm{p}<.05)$.

\section{DISCUSSION}

The finding that the CR(ECS) group made significantly more responses in extinction than did the $\mathrm{CR}(\mathrm{SO})$ group is consistent with earlier findings.

A critical finding of this study is that for Ss trained on a FR schedule, using a discrete-trial procedure to slow response rate, the immediate administration of ECS following footshock did eliminate or reduce suppression of responding. This suggests that in earlier studies where ECS failed to reduce response suppression for FR-trained Ss (Adams, Peacock, \& Hamrick, 1967; Young \& Galluscio, 1970), the absence of response suppression was
Iable 2

Mean Number of Responses Per Minute

$\begin{array}{lccc}\text { Group } & \begin{array}{c}\text { Acqui- } \\ \text { sition }\end{array} & \begin{array}{c}\text { I.inst } \\ \text { Istinction }\end{array} & \begin{array}{c}\text { Total } \\ \text { Ixtinction }\end{array} \\ \text { CR(1:CS) } & 32.65 & 12.37 & 6.27 \\ \text { CR(SO) } & 36.49 & 5.62 & 3.51 \\ \text { IR(LCS) } & 16.70 & 9.00 & 5.07 \\ \text { IR(SO) } & 14.97 & .87 & 2.96\end{array}$

due to the higher rate of response generated by the FR schedule and not due to the effects of the FR schedule itself. Although the present results support a memory-consolidation hypothesis, it is difficult to interpret findings that indicate that when response rate is high, ECS fails to produce RA. If the effect of ECS is the disruption of a memory-consolidation process, the response rate during acquisition and prior to the adminsitration of ECS should be irrelevant.

A second critical finding of this study is the failure of the FR-trained Ss to show the partial-reinforcement effect (PRE) in extinction. In fact, the CRF-trained Ss made more responses during the full extinction period and significantly more responses during the first minute of extinction than did the FR-trained Ss. This result is in agreement with the earlier findings of Young and Galluscio, although in that study the difference between FR-trained Ss and CRF-trained Ss did not reach statistical significance.

The loss of the PRE following treatment does not fit within any current theoretical framework, and whether or not it is peculiar to FR-trained Ss remains to be determined.

\section{REFERENCES}

ADAMS, H. E., PEACOCK, L, J., \& HAMRICK, D. D. FCS and one-trial learning: Retrograde amnesia or disinhibition? Physiology \& Behavior, 1967, 2, 435-437.

HERIOT, J. T., \& COLEMAN, P. D. The effect of electroconvulsive shock on retention of a modified "one-trial" conditioned avoidance. Journal of Comparative \& Physiological Psychology, 1962, 55, 1082-1084.

HUDSPETH, W. J., McGAUGH, J. L., \& THOMPSON, C. W. Aversive and amnesic effects of electroconvulsive shock. Journal of Comparative \& Physiological Psychology, $1964,57,61 \cdot 64$.

LEWIS, D. J. Sources of experimental amnesia. Psychological Review, 1969, 76, 461-472.

MADSEN, M. C., \& McGAUGH, J. L. The effect of ECS on one-trial avoidance learning. Journal of Comparative \& Physiological Psychology, 1961, 54, 522-523.

McGAUGH, J. L. Time-dependent processes in memory storage. Science, 1966, 153 1351-1358.

SPEVACK, A. A., \& SUBOSKI, M. D. Retrograde effects of electroconvulsive shock on learned responses. Psychological Bulletin, 1969, 72, $66-76$

YO'VG, A. G., \& GALLLSCIO, F. H. Failure of ECS to produce retrograde amnesia following partial reinforcement training. Psychonomic Science, 1970, 18, 175-176. 